split alpha-methyl-glucoside; they retain, however, or regenerate after the heating, most of their ability to split maltose.

It follows, therefore, that the inversion of sucrose by taka-diastase is not even partially due to takamaltase but to a distinct taka-sucrase. It seems reasonable also to believe with Pringsheim that the slight alpha-glucosidase action observed by Weidenhagen in concentrated taka-diastase preparations was due to the admixture with the predominant glucomaltase in mould of a small quantity of glucosidomaltase.

A further proof that yeast maltase and taka. maltase are different was furnished by a study of the effect of taka-diastase on yeast maltase solution. Yeast maltase solution incubated for a definite time interval with a sufficient concentration of takadiastase loses completely its ability to hydrolyze either alpha-methyl-glucoside or maltose. The ability of the taka-maltase to split maltose is not, however, removed under these conditions. Taka-diastase thus contains an inhibitor for yeast glucosido-maltase. The inhibitor is heat labile, non-dialyzable and distinct from taka-maltase.

The nature of the 'heat-stable' taka-maltase, the manner of inhibition of the yeast maltase, and in particular the effect of the inhibitor in taka-diastase upon maltose fermentation by zymase will be reported in detail elsewhere.

\section{J. LeIBowITZ.}

S. Hestrin.

Department of Hygiene and Bacteriology,

The Hebrew University,

Jerusalem.

Feb. 6 .

1 Leibowitz, J., Z. physiol. Chem., 149, 184 (1925) ; Leibowitz and 1 Leibowitz, J., Z, physiol. Chem.
Mechlinsky, ibid., 154, 64 (1926).

'See, for example, Pringsheim, Borchardt and Loew, $Z$. physiol. Chem., 202, 23 (1931); Pringsheim and Loew, ibid., 207, 241 (1932) Karstroem, H., Biochem. Z., 231, 399 (1931); Tauber and Kleiner, J. Gen. Physiol., 16, 767 (1932-33) ; J. Biol. Chem., 105, 679 (1934). ' Weidenhagen R. "Ergebnisse der Enzymforschung", Yol (1932); Z. physiol. Chem., 216, 255 (1933), and elsewhere.

\section{Action of Molybdenum in Nutrition of Milking Cattle}

A LARGE area under pasture in Somerset cannot be grazed by cows during the normal grazing season (April-October) without milk yields falling rapidly, causing marked loss of condition and even death. The disorder, which has been known for very many years, is marked by extreme diarrhoea; other cattle and sheep also scour on such herbage, though the loss of condition is not so obvious as with the milking animal. Such fields are described as being 'teart'. The area involved is estimated at about 20,000 acres by Gimingham ${ }^{1}$, and the annual loss to the farming community must be very great. The available information seems to rule out bacteria, parasites, water supply or a particular herb as causal agents, and points to the presence of some constituent of the soil taken up by the herbage ${ }^{2}$.

Spectrographic examination of a few samples kindly supplied to us by Mr. A. W. Ling and Mr. W. R. Muir of the University of Bristol showed the presence of molybdenum in 'teart' herbage. A more extensive and systematic examination which we have since conducted on 'teart' and 'non-teart' fields in Somerset has confirmed the fact that the molybdenum content of 'teart' herbage is considerably higher than that of the 'non-teart' fields situated close by.
There is no apparent correlation between the total or HCl-soluble molybdenum of the soil and that of the herbage. Comparisons are, however, complicated by the fact that 'teart' and 'non-tcart' fields are managed in such a way that the herbage is at different stages of growth at any one time of the year.

We have fed soluble molybdates in quantities equivalent to those provided in an average daily ration of really 'teart' herbage $(1.36 \mathrm{gm}$. Mo per head per day) to five dry cows at Jealott's Hill, and in three cases have produced extreme scouring and loss of condition similar to that which occurs in 'teart' fields in Somerset. Whether the molybdenum is directly responsible or whether it catalyses a toxic product in the rumen we do not yet know. It is generally stated in the 'teart' areas that horses are not affected, but it is impossible to say at present if this is due to the simple stomach or to differences in grazing habit.

The investigation is still being pursued. Our thanks are due to Mr. Milbourn of I.C.I. (Metals), Ltd., for the spectrographic examination of the early samples from Bristol.

W. S. Frrauson.

A. H. LEwIS.

Jealott's Hill Research Station, S. J. Watson. Bracknell,

Berks.

Feb. 22.

1 Gimingham, C. T., J. Board Agric., 17, 529 (1910).

' Muir, W. R., Agric. Progress, 13, 53 (1936).

Potential Changes in the Ears of Reptiles and Fish

Wever and Bray's work has shown that in mammals the cochlea behaves like a microphone, giving electric oscillations which are an accurate transcription of the sound waves. The most plausible explanation of the effect is that of Hallpike and Rawdon Smith, namely, that it is due to the vibration of a polarized membrane separating endolymph and perilymph, but other hypotheses have been put forward.

The object of this communication is to direct attention to the similar effect in the inner ears of cold-blooded vertebrates. In alligators there is a cochlea, and it is not surprising to find potential changes, as in mammals, copying the sound waves. In lizards the potentials which can be detected in the inner ear are of the same form, but are much smaller. In tortoises they are often too small to be distinguishable from artefacts due to electrode movement. In the eel, however, the inner ear structures are more accessible and large potential oscillations can be recorded from the saccule when the head is exposed to vibration. The saccular response in the pike, described by Piper $(1910)^{1}$, is presumably due to the same cause. The frequency of the potential changes which can be induced in the inner ear seems to be limited merely by the frequency at which the structures can be made to vibrate; the maximum frequency of response in the fibres of the auditory nerve is much lower, since there must be time for recovery after each impulse.

\footnotetext{
Physiological Laboratory, Cambridge. March 7.

Piper, H., Arch. Anat. u. Physiol., Physiol. Supp., 1, 1910 (1910).
} 